\title{
Removal of Radionuclides from Fukushima Daiichi Waste Effluents
}

\author{
Lehto, Jukka
}

2019-04-03

Lehto , J , Koivula , R , Leinonen , H , Tusa , E \& Harjula , R 2019, ' Removal of

Radionuclides from Fukushima Daiichi Waste Effluents ', Separation and Purification

Reviews , vol. 48 , no. 2 , pp. 122-142 . https://doi.org/10.1080/15422119.2018.1549567

http://hdl.handle.net/10138/325769

https://doi.org/10.1080/15422119.2018.1549567

unspecified

acceptedVersion

Downloaded from Helda, University of Helsinki institutional repository.

This is an electronic reprint of the original article.

This reprint may differ from the original in pagination and typographic detail.

Please cite the original version. 


\section{Removal of radionuclides from Fukushima Daiichi waste effluents}

Jukka Lehto ${ }^{1 *}$, Risto Koivula ${ }^{1}$, Heikki Leinonen ${ }^{2}$, Esko Tusa $^{3}$, Risto Harjula ${ }^{1}$

1) Department of Chemistry - Radiochemistry, P.O.Box 55, FIN-00014 University of Helsinki, Finland

2) Carrum Oy, Välimäentie 13, Järvenpää, Finland

3) Consultant, Kauniainen, Finland

* corresponding author, jukka.lehto@helsinki.fi

\section{ABSTRACT}

This paper describes the processes used at the Fukushima Daiichi plant, Japan, to purify the waste effluents generated in the cooling of damaged reactors. These include primary cesium removal with the Kurion zeolite system and the SARRY system utilizing silicotitanate to remove radiocesium from water recirculated to reactors for cooling. Another process is the ALPS system to purify the retentates of the reverse osmosis plant to further purify the water from radionuclides after primary cesium separation. In ALPS, a major role is played by the transition metal hexacyanoferrate product CsTreat and sodium titanate SrTreat in the removal of radiocesium and radiostrontium, respectively. The performance of these four exchangers (zeolite, silicotitanate, hexacyanoferrate, and sodium titanate) are critically analysed with respect to processing capacities and the decontamination factor obtained in the processes. Furthermore, general information on preparation, structure, and ion exchange of these ion-exchanger categories are given with additional information on their use in nuclear waste effluent treatment processes. Finally, the importance of selectivity and associated factors are discussed. 


\section{INTRODUCTION}

Following a major earthquake, a powerful tsunami disabled the power supply to three reactors at the Fukushima Daiichi nuclear power plant in Japan on March 11, 2011. As the fuel was not cooled these reactors melted in the following three days. Even though the nuclear chain reaction had stopped, due to the continuing radioactive decay of fission products the fuel was very hot (well above $1000^{\circ} \mathrm{C}$ ) and caused the meltdown. To cool the damaged reactors, injection of sea water with fire department trucks was initiated one to three days after onset of the accident. After approximately two weeks, electrical power was restored to the plant and fresh water was injected into the reactors instead of seawater. The injected water accumulated in the basement of the reactor buildings and in the turbine halls. The radioactivity content of the water was very high since the water was in direct contact with melted fuel. As a highly soluble and readily volatile alkali metal, radioactive cesium isotopes ${ }^{134} \mathrm{CS}$ and ${ }^{137} \mathrm{Cs}$ formed the greatest fraction of the radioactivity in the cooling water. ${ }^{137} \mathrm{Cs}$ is a fission product with a half-life of 30 years while ${ }^{134} \mathrm{Cs}$ is a neutron activation product with a half-life of 2.1 years. They are both of great radiological concern due to emission of high-energy gamma rays. At the onset of the accident, both cesium isotopes were present at approximately the same contents in the fuel. In the seven years since the event, the fraction of ${ }^{134} \mathrm{Cs}$ activity has decreased to about $10 \%$ of that of ${ }^{137} \mathrm{Cs}$. The second most important component in the waste waters was formed by ${ }^{90} \mathrm{Sr}$, which has a half-life of 29 years. After the accident the waste also contained ${ }^{89} \mathrm{Sr}$. However, due to its short half-life of just 51 days this radionuclide has decayed completely. As strontium has lower solubility and volatility than cesium, its concentration in the contaminated waters was, however, considerably lower than that of the radiocesium isotopes. In addition to radiocesium and radiostrontium, the waters contain numerous other radionuclides.

To prevent overflow of these highly contaminated waters from the reactor buildings into the sea, the operator of the plant (TEPCO, Tokyo Electric Power Company) hired contractors to build waste water treatment systems to enable circulation of the cooling water. This paper reviews the various systems constructed at the Fukushima Daiichi plant for this purpose. The performance and radionuclide separation efficiency of the systems are described. Special attention is paid to the highly selective inorganic ion exchangers CsTreat and SrTreat, which were used to separate radioactive cesium and strontium, respectively, at the far end of the separation processes. These exchangers were developed by the Radiochemistry Unit of the University of Helsinki, Finland and 
the Fortum company, Finland, and are manufactured by the latter. The scientific and technical literature on Fukushima waste treatment is very limited. The data for this article were extracted mostly from TEPCO press releases (http://www.tepco.co.jp/en/press/corp-com/release/indexolde.html). These releases contain altogether 335 reports from 2011 to 2017 entitled "Situation of storing and treatment of accumulated water including highly concentrated radioactive materials at Fukushima Daiichi Nuclear Power Station." Each report contains a schematic picture of the water treatment systems and provides water volumes and performance data. An example of such a picture is shown in Fig. 1. Later in this article, we refer to these reports as "TEPCO press releases." In addition, the TEPCO Press Conference handouts were an important source of information.

Figure 1. An example schematic of the water treatment system at the Fukushima Daiichi plant as presented in the TEPCO press releases "Situation of storing and treatment of accumulated water including highly concentrated radioactive materials at Fukushima Daiichi Nuclear Power Station" (http://www.tepco.co.jp/en/press/corp-com/release/2015/1265264 6844.html).

The Fukushima Daiichi nuclear waste effluent treatment is the largest ever nuclear waste treatment process. Various waste treatment systems and purification media, many of which represent today's best available technology, have been tested at the plant during the last eight years. Therefore, it is essential to describe and critically analyse the processes with respect to their radionuclide removal performance. This is also needed in further development of nuclear waste treatment processes and purification media.

\section{FIRST PURIFICATION SYSTEM IN JUNE TO SEPTEMBER 2011: ZEOLITE AND COPRECIPITATION}

Construction of the first system for the purification and circulation of cooling waters started in April 2011; the system was operational on June 17, 2011. This system was based on a zeolite separation of radiocesium and coprecipitation of cesium and other radionuclides. The purified water was further treated with a reverse osmosis system, from which the permeate was directed back to reactors for cooling and the saline retentate into storage tanks for further treatment (see next section). The zeolite part of the system was offered by Kurion Inc., USA, the coprecipitation by Areva/Veolia, France, and the reverse osmosis by Hitachi, Japan. In this system, zeolite separation was first, coprecipitation was second, and reverse osmosis was performed at the end. 
The Kurion cesium removal system is based on four parallel lines, each with four $1.2 \mathrm{~m}^{3}$-zeolite beds in series (Fig. 2). The zeolite used in the system is herschelite, a special-type chabazite with the general formula of $\left(\mathrm{Na}_{2}, \mathrm{~K}_{2}, \mathrm{Ca}, \mathrm{Sr}, \mathrm{Mg}\right)_{2}\left[\mathrm{Al}_{2} \mathrm{Si}_{4} \mathrm{O}_{12}\right]_{2} \times 12 \mathrm{H}_{2} \mathrm{O}$. Zeolites, the tunnel-structured aluminosilicates, and their use in nuclear waste treatment are discussed in detail later.

Figure 2. The Kurion zeolite system at the Fukushima Daiichi plant for the removal of radiocesium from contaminated waters generated in the cooling of damaged reactors. In front of the zeolite beds is a surfactant-modified zeolite bed for removal of oil and technetium and at the far end a silverimpregnated zeolite bed for radioiodine removal. TEPCO Press Conference handout dated June 17, 2011.

The Areva/Veolia coprecipitation (Fig. 3) was a two-stage system consisting of Multiflo ${ }^{\circledR}$ and Actiflo ${ }^{\circledR}$ sub-systems in series (1). In this system, radiocesium is coprecipitated with nickel hexacyanoferrate (general formula $\mathrm{M}_{2} \mathrm{NiFe}(\mathrm{CN})_{6}$, where $\mathrm{M}$ is an alkali metal) and radiostrontium with barium sulfate $\left(\mathrm{BaSO}_{4}\right)$. Presumably the system also contained coprecipitation of hydrolysable metals with ferric hydroxides. At the end of the process, the sludge was separated with a lamella-settling tank. An already existing system was dismantled from a site (probably in Europe) and moved to Japan.

Figure 3. The Areva/Veolia coprecipitation system used in June to September 2011 at the Fukushima Daiichi plant to purify contaminated waters. TEPCO Press Conference handout dated October 29, 2011.

The combined Kurion-Areva/Veolia purification system was running for only three months as the Areva/Veolia part of the system was taken out of operation at the end of September 2011. During the three months, the system processed in total $80000 \mathrm{~m}^{3}$ of water for circulation back to the damaged reactors. In this period, the ${ }^{137} \mathrm{Cs}$ activity of the water to be treated was $1.5 \times 10^{9} \mathrm{~Bq} / \mathrm{L}$, corresponding to a chemical concentration of $3 \times 10^{-5} \mathrm{~mol} / \mathrm{L}$. The chloride concentration, representing salinity, decreased from $16 \mathrm{~g} / \mathrm{L}$ to $5 \mathrm{~g} / \mathrm{L}$. The decontamination factor (i.e., the ratio of activity concentration before treatment to that after treatment) for ${ }^{137} \mathrm{Cs}$ of the zeolite was on average fairly low (260), while the coprecipitation yielded decontamination factors between 200 and 20000 . The overall decontamination factor of the whole system was good, varying between 
$3 \times 10^{4}$ and $2 \times 10^{6}$. The system, however, produced large volumes of secondary waste (in total 820 $\mathrm{m}^{3}$ ), of which $580 \mathrm{~m}^{3}$ was sludge from the coprecipitation system and $240 \mathrm{~m}^{3}$ was spent zeolite. Generation of unacceptably high volumes of secondary waste was probably the reason why the Areva/Veolia coprecipitation was completely taken out of operation. From September 2011 onwards, the Kurion zeolite system continued operation but was mostly replaced by the more efficient SARRY system utilizing silicotitanate for cesium removal.

Due to their batch operation mode nature, precipitation processes, despite using radionuclidespecific precipitation agents such as hexacyanoferrates, are far less effective than column mode processes utilizing packed beds. This is why the Areva/Veolia system had such a low processing capacity and produced such high volumes of secondary waste. Zeolites, in turn, even though they are clearly more selective than conventional organic ion-exchange resins, are not highly selective for any ions. This means that whenever the solution contains considerable concentrations of competing macro ions their separation performance for cesium is low to intermediate. The most important competing macro ions are sodium, potassium, calcium, and magnesium, which are present in all natural waters and in most nuclear waste effluents. In sea water their concentrations are $0.47 \mathrm{~mol} / \mathrm{L}$ (sodium), $0.01 \mathrm{~mol} / \mathrm{L}$ (potassium), $0.01 \mathrm{~mol} / \mathrm{L}$ (calcium), and $0.05 \mathrm{~mol} / \mathrm{L}$ (magnesium). In the early phases of purification the water was essentially sea water with a salt content of 3.5\%. The first reported chloride concentration in June 2011 was $16 \mathrm{~g} / \mathrm{L}$, which is close to the average sea water concentration of $19 \mathrm{~g} / \mathrm{L}$. Tsukada et al. (2) reported that the cesium distribution coefficient of Kurion chabazite in pure water is about $15000 \mathrm{ml} / \mathrm{g}$ while in sea water it is only about $800 \mathrm{ml} / \mathrm{g}$ (derived from data in Fig. 8 in Tsukada et al. paper) at a cesium concentration of $0.01 \mathrm{mmol} / \mathrm{L}$. The decrease clearly illustrates the low selectivity of chabazite, true to any zeolite. Selectivity is the key factor in both the decontamination factor and processing capacity; the higher the selectivity the higher the decontamination factor and the processing capacity (discussed later in detail). At this stage we note that the distribution coefficient is directly proportional to the processing capacity. For example, if the distribution coefficient determined in batch mode is $800 \mathrm{ml} / \mathrm{g}$, this means that $800 \mathrm{ml}$ of waste can be processed to $50 \%$ breakthrough with $1 \mathrm{~g}$ of sorbent in a column mode. This corresponds to $0.8 \mathrm{~m}^{3}$ per $1 \mathrm{~kg}$. This is consistent with the observed performance of Kurion zeolite reported in Table $2\left(0.38 \mathrm{~m}^{3} / \mathrm{kg}\right)$. It is clear that in the Fukushima purification process the zeolite beds were not run to a water volume corresponding to $50 \%$ breakthrough but to a sufficiently low 
volume that assured the highest achievable decontamination factor. This is why the observed processing capacity was only about half of that derived from the distribution coefficient.

From June to September 2011 reverse osmosis decreased the water salinity by a factor of 450 on average, calculated from the decrease in chloride concentration.

Table 2. Summary of the performance of the combined Areva/Veolia coprecipitation and Kurion zeolite purification system in the removal of ${ }^{137} \mathrm{Cs}$ for the water circulation in June to September 2011. Derived from data provided in TEPCO press releases.

We conclude that the first purification phase yielded high decontamination factors for radiocesium but generated unacceptably high volumes of secondary waste, precipitation sludge, and spent zeolite. The technology did not represent the best available technique but was based on established but somewhat outdated technology. It was, however, important to rapidly install a water treatment system to prevent the overflow of contaminated water from reactor buildings into the surroundings. With this respect the rapidly built zeolite/coprecipitation system worked well as a first aid.

\footnotetext{
Radionuclides of cesium

In irradiated nuclear fuel there are three radioisotopes of cesium $\left({ }^{134} \mathrm{Cs},{ }^{135} \mathrm{Cs},{ }^{137} \mathrm{Cs}\right)$. Of these, ${ }^{135} \mathrm{Cs}$ and ${ }^{137} \mathrm{Cs}$ are fission products while ${ }^{134} \mathrm{Cs}$ forms in a neutron activation reaction ${ }^{133} \mathrm{Cs}(\mathrm{n}, \mathrm{\gamma}){ }^{134} \mathrm{Cs}$ of stable cesium. The half-life of ${ }^{134} \mathrm{Cs}$ is fairly short (2.1 years) and thus does not pose a long-term radiological problem. In the short term, it is as important as the longerlived ${ }^{137} \mathrm{Cs}$ since both emit high-energy gamma rays. In the Fukushima Daiichi fuel and environmental releases, the activity concentration of ${ }^{134} \mathrm{Cs}$ and ${ }^{137} \mathrm{Cs}$ were approximately the same. Today, in 2018 , the activity of ${ }^{134} \mathrm{Cs}$ is only about one tenth of that of ${ }^{137} \mathrm{Cs} .{ }^{135} \mathrm{Cs}$ and ${ }^{137} \mathrm{Cs}$ are fission products of ${ }^{235} \mathrm{U}$ and ${ }^{239} \mathrm{Pu}$; the fission yields are high at $6.6 \%(\mathrm{U})$ and $7.6 \%$ $(\mathrm{Pu})$ for the former and 6.2\% (U) and 6.6\% (Pu) for the latter. Mass-wise, both thus occur at the same levels in irradiated fuel. Due to their very different half-lives of 2300000 years $\left({ }^{135} \mathrm{Cs}\right)$ and 30 years $\left({ }^{137} \mathrm{Cs}\right)$, the activity of the latter is about 100000 times greater than that of ${ }^{135} \mathrm{Cs}$. Accordingly, ${ }^{135} \mathrm{Cs}$ does not form any radiological risk in a nuclear accident but is in
} 
the very long-term one the most important radionuclides with respect to potential release and migration of radionuclides from spent nuclear fuel into the biosphere.

With the exception of the extremely rare francium, cesium is the heaviest alkali metal. Due to its large size and low charge (+1), cesium is the most electropositive element and forms highly soluble ionic compounds. Due to this radioactive cesium isotopes are readily released from nuclear fuel in accidental events, such as the event at the Fukushima Daiichi plant. In spent nuclear fuel, most radiocesium occurs as dissolved in $\mathrm{UO}_{2}$ matrix and in metallic precipitates. However, a large fraction occurs in the readily soluble fraction (also called instant release fraction), in $\mathrm{UO}_{2}$ grain boundaries, cracks, and caps. After decay of the very short-lived radionuclides (such as ${ }^{131} \mathrm{I}$ ), ${ }^{137} \mathrm{Cs}$ forms together with ${ }^{90} \mathrm{Sr}$ most (99\%) of the radioactivity in spent nuclear fuel and in nuclear fallouts. Of these two radionuclides, ${ }^{137} \mathrm{Cs}$ poses a higher radiological risk due to its high gamma energy, high solubility, and tendency to effectively accumulate in humans.

Due to their low charge density, $\mathrm{Cs}^{+}$ions do not effectively sorb on conventional organic ionexchange resins. However, there are some inorganic compounds, both natural and synthetic, that show selectivity towards cesium ions. In the environment, mica and clay minerals are the most effective sorbing minerals for cesium. For industrial nuclear waste purification purposes, the most commonly used sorbents are zeolites, silicotitanates, and transition metal hexacyanoferrates, of which the latter is the most selective. These three categories of sorbents are discussed in detail later in the paper.

SECOND PURIFICATION SYSTEM FROM SEPTEMBER 2011 ONWARDS: SILICOTITANATE WITH ZEOLITE AS A BACK-UP

On August 17, 2011 a new water purification system parallel to Kurion-Areva/Veolia system was commissioned. The new system was called SARRY (Simplified water retrieval and recovery system) and was based on radiocesium separation with a crystalline silicotitanate (CST) (3). This exchanger is produced in sodium form by UOP, USA, under the trademark IONSIV ${ }^{\text {TM }}$ R9120 (formerly IE-911) (https://www.uop.com/?document=uop-ionsiv-r9120-selective-media\&download=1).

Silicotitanates and their use in nuclear waste treatment are discussed later in detail. The system was 
designed and constructed by Shaw, USA, Avantech Inc., USA, and Toshiba, Japan. In SARRY there are four $1.95-\mathrm{m}^{3}$ (1040 kg) ion-exchange beds in series. Beds are operated in a "merry-go-round" mode: when a breakthrough is observed in the last column, the first column is removed and a fresh column is placed to the end of the series. The columns are heavily shielded due to build-up of high ${ }^{137} \mathrm{Cs}$ loading into the columns (planned maximum value in one column $200000 \mathrm{Ci}=7.4 \times 10^{15} \mathrm{~Bq}$ ). In approximately one month after commissioning of the SARRY system, the AREVA/Veolia system was removed from operation and the SARRY system was operational in parallel with the Kurion zeolite system. From June 2012 onwards the SARRY system was mainly responsible for cesium removal while the Kurion system remained as a backup system. In 2011 to 2017 a total of 1.88 million cubic meters of waste water was treated with these systems (Fig. 4). From the maximum annual volume of 0.35 million cubic meters in 2013 the volume has decreased to almost half of that in 2017 . The share of the Kurion system of the total treated volume was $62 \%$ in 2011 , on average $17 \%$ from 2012 to 2016 , and only $5 \%$ in 2017.

Figure 4. Volumes of waste waters treated by the SARRY and Kurion water treatment systems at the Fukushima Daiichi plant from 2011-2017. Derived from TEPCO press releases.

The ${ }^{137} \mathrm{Cs}$ activity concentration of the feed to the system decreased from greater than $10^{9} \mathrm{~Bq} / \mathrm{L}$ in 2011 by two orders of magnitude to approximately $2 \times 10^{7} \mathrm{~Bq} / \mathrm{L}$ in 2016 . Thereafter, the feed activity concentration of SARRY has remained at this level while the feed activity concentration of the Kurion system increased to $9 \times 10^{7} \mathrm{~Bq} / \mathrm{L}$ in 2017 , the reason of which is unknown.

Figure $5 .{ }^{137} \mathrm{Cs}$ concentration $(\mathrm{Bq} / \mathrm{L})$ in the feed to the SARRY and Kurion water treatment systems at the Fukushima Daiichi plant from 2011-2017. Derived from TEPCO press releases. One GBq/L (10 $\mathrm{Bq} / \mathrm{L})$ of ${ }^{137} \mathrm{Cs}$ corresponds to chemical concentration of $0.2 \mu \mathrm{mol} / \mathrm{L}$ and one $\mathrm{MBq} / \mathrm{L}\left(10^{6} \mathrm{~Bq} / \mathrm{L}\right)$ to 0.2 $\mathrm{nmol} / \mathrm{L}$.

The salinity of the waste water has decreased considerably since 2011. Initially, the water was sea water that was injected into the reactor buildings. The first reported chloride concentration in June 2011 was $16 \mathrm{~g} / \mathrm{L}$, close to the value in sea water (19 g/L). From mid-2013 onwards the chloride concentration has been below $1 \mathrm{~g} / \mathrm{L}$; from 2016 to 2017 the average concentration was $0.26 \pm 0.07$ $\mathrm{g} / \mathrm{L}$. The reverse osmosis process removes most of the salts from the liquids, leaving typically only 1 
to $2 \mathrm{ppm}(0.001-0.002 \mathrm{~g} / \mathrm{L})$ chloride in the solution. Due to the daily intrusion of $500 \mathrm{~m}^{3}$ (by February 2016) of groundwater and rain water into the reactor buildings, the salinity has increased by two orders of magnitude as the circulated waters return to the water purification system. The total daily volume of waters circulated to the reactors from the water purification system is approximately 200 $\mathrm{m}^{3}$. Thus we may assume that the salinity of the intruding groundwater and rain water is reduced by a factor of about 1.5. Several countermeasures have reduced the daily amount of groundwater and rain water intrusion to $110 \mathrm{~m}^{3}$ by February 2018 (TEPCO Fukushima Daiichi prompt report, April 23, 2018).

Figure 6. Chloride concentration $(\mathrm{ppm}=\mathrm{mg} / \mathrm{L})$ in Fukushima Daiichi plant waste waters. Derived from TEPCO press releases.

During the operation years 2011 to 2017 , the decontamination factor for radiocesium (DF) of the two systems has varied in a wide range of about two orders of magnitude. The decontamination factors of the two systems were practically at the same level. On average, the DF of SARRY was 71 000 (range 1900-560 000) and 61000 (range 2600-320 000) for the Kurion system. In both systems there was no correlation observed between the DF and the salinity (chloride concentration), which is somewhat surprising since one would expect higher DF as the salinity decreased. After removal of the Areva/Veolia system, the DF of the Kurion system increased by two orders of magnitude. During this time the salinity, which affects performance, did not change very much yet. Thus, we may assume that the Areva/Veolia system had an antagonist effect on the performance of the Kurion system. Furthermore, the Kurion system run alone performed as well as the combined Kurion-Areva/Veolia system.

Figure 7. Decontamination factor for ${ }^{137} \mathrm{Cs}$ of the contaminated water purification systems at the Fukushima Daiichi plant. Derived from data provided in TEPCO press releases.

While there was no difference in DF observed between the two water treatment systems, the processing capacities varied considerably (Table 3 ). The Kurion system created 2.5 times more 
secondary solid waste even though it was used for only $20 \%$ of the waters. The processing capacity, (i.e., the number of bed volumes of water per unit bed volume of exchanger) treated by SARRY was about ten times higher than that of the Kurion system. Considering the clear decrease in salinity of the waters, one would expect that much higher processing capacities would have been achievable in the later years (such as 2013 onwards). However, the renewal frequency of the beds has not changed significantly over the whole 6.5-year period. In the case of the Kurion system, 320 to 410 $\mathrm{m}^{3}$ of waste was processed per bed in 2011 but the volume increased on average to only $470 \mathrm{~m}^{3}$ in 2014 to 2017. In the case of SARRY the increase was somewhat higher, from 1700 to $2700 \mathrm{~m}^{3}$ in 2012 to on average $7300 \mathrm{~m}^{3}$ in 2014 to 2017. Furthermore, due to the decreasing ${ }^{137} \mathrm{Cs}$ concentration in the feed, the ${ }^{137} \mathrm{Cs}$ loading in beds greatly decreased over the years. Assuming an average ${ }^{137} \mathrm{Cs}$ concentration of $10^{9} \mathrm{~Bq} / \mathrm{L}$, the average radiocesium loading in one bed for SARRY before October 10, 2011 was approximately $60000 \mathrm{Ci}\left(2 \times 10^{15} \mathrm{~Bq}\right)$ while that of the Kurion system was approximately $10000 \mathrm{Ci}\left(4 \times 10^{14} \mathrm{~Bq}\right)$. In 2016 the corresponding values were much lower, namely $3000 \mathrm{Ci}$ (SARRY) and $300 \mathrm{Ci}$ (Kurion). Even in the early phases, the planned maximum value of $200000 \mathrm{Ci}$ per bed for SARRY was not exceeded, not mentioning later years. Running the columns much longer thus would not have been limited by excessive build-up of cesium loading in the columns.

Table 3. Processing capacity data for SARRY and Kurion water treatment systems at the Fukushima Daiichi plant. Derived from data provided in TEPCO press releases.

\begin{tabular}{|l|c|c|}
\hline Years 2011-2017 & Kurion & SARRY \\
\hline Number of beds & 763 & 392 \\
\hline Cubic meters of exchanger used & 917 & 390 \\
\hline Tonnes of exchanger used & 824 & 3760 \\
\hline $\begin{array}{l}\text { Processing capacity } \\
\text { (bed volumes) }\end{array}$ & 392 & 3.62 \\
\hline $\begin{array}{l}\text { Cubic meters of waste treated with } \\
1 \text { kg of exchanger }\end{array}$ & 0.44 & \\
\hline
\end{tabular}

${ }^{1}$ Processed waste water volume divided by the volume of exchanger beds

\section{Radionuclides of strontium}


The most important strontium radionuclide is ${ }^{90} \mathrm{Sr}$. In Fukushima Daiichi waste effluents the activity concentration of ${ }^{90} \mathrm{Sr}$ was highest after that of ${ }^{137} \mathrm{Cs}$, being about one tenth of that of ${ }^{137} \mathrm{Cs}$. ${ }^{90} \mathrm{Sr}$ is a fission product of ${ }^{235} \mathrm{U}$ and ${ }^{239} \mathrm{Pu}$, with fission yields of $5.7 \%$ and $2.0 \%$, respectively. ${ }^{90} \mathrm{Sr}$ is a pure beta emitter with beta particle maximum energy of $0.54 \mathrm{MeV}$. It is also parent to a shortlived ${ }^{90} \mathrm{Y}$, which emits high maximum energy beta particles of $2.27 \mathrm{MeV}$. The two nuclides are typically in radiochemical equilibrium, meaning that their activities are the same. The half-life of ${ }^{90} \mathrm{Sr}$ is approximately the same as that of ${ }^{137} \mathrm{Cs}$ (29 years). Another radiostrontium isotope at approximately the same fission yield as ${ }^{90} \mathrm{Sr}$ is ${ }^{89} \mathrm{Sr}$, which also is a pure beta emitter with maximum energy beta particles of $1.48 \mathrm{MeV}$. The half-life of ${ }^{89} \mathrm{Sr}$ is, however, only 50 days and thus it is important only in the early months after the fission process has ended. Radiologically, ${ }^{90} \mathrm{Sr}$ is not as harmful as ${ }^{137} \mathrm{Cs}$ but when ingested enriches primarily into bones.

Strontium is an alkaline earth metal and its chemistry resembles calcium, the next lighter element in the alkaline earth metals series. As an alkaline earth element, strontium has only one oxidation state (+II) and forms $\mathrm{Sr}^{2+}$ ions in solutions. Its compounds are typically ionic and very soluble. Only carbonates, phosphates, sulfates, and oxalates are less soluble. In spent nuclear fuel Sr is primarily as dissolved in uranium dioxide matrix, but a small fraction (approximately 1\%) is in the so-called instant release fraction in grain boundaries, cracks, and gaps.

Since the charge of the strontium ion is low and its size is rather large, the electrostatic affinity towards ion exchangers is typically not very high. There are, however, some exceptions such as crown ethers, titanates, and silicotitanates, of which the ion-exchange properties of the latter two will be described in detail later.

\section{PURIFICATION OF REVERSE OSMOSIS RETENTATE BY ALPS}

To purify the saline reverse osmosis retentate from radionuclides, a new system known as ALPS (Advanced Liquid Processing System) was installed at the Fukushima Daiichi plant in 2013. The purpose of the system was to reduce the radionuclide concentrations to levels that would permit discharge of the treated waters to sea. Initially, altogether 62 radionuclides were to be removed. Today only one third of these radionuclides are left; all others have decayed. There are currently three parallel ALPS systems. The first one, designed by Energy Solutions, USA, was commissioned in 
March 2013. This system consists of three phases, namely pretreatment, sorption, and endpolishing (Fig. 8). In pretreatment, ferric hydroxide floc removes primarily hydrolysable radionuclides, such as transuranium elements, ${ }^{60} \mathrm{Co}$, and ${ }^{54} \mathrm{Mn}$. The carbonate precipitation removes calcium and magnesium, which strongly interfere with the removal of radionuclides in the sorption phase, particularly in the case of strontium. Carbonate precipitation not only lowers the calcium and magnesium concentrations from hundreds of ppm to less than $5 \mathrm{ppm}$ but also removes ${ }^{90} \mathrm{Sr}$ in excess of $90 \%$ (4). The precipitate forming at this stage is a mixture of calcium carbonate and magnesium hydroxide. Magnesium is precipitated as hydroxide since it is much less soluble than magnesium carbonate. The overall removal of radionuclides in the pretreatment phase was reported to exceed $95 \%$ in the laboratory tests supporting the design of the system (4). The sorption phase consists of sixteen $1-\mathrm{m}^{3}$ sorbent beds containing inorganic ion exchangers, chelating organic resins, activated carbons and hybrid organic/inorganic sorbents. According to the TEPCO Press Conference handout from June 25, 2012, there are seven types of sorbents (Table 4). A major role in these beds are playing by the cesium-selective $\operatorname{CsTreat~}^{\circledR}$ (hexacyanoferrate) and the strontium-selective SrTreat ${ }^{\circledR}$ (titanate) materials developed and/or manufactured by the authors of this article (5). The properties of these sorbents will be discussed in detail later. A second Energy Solutions ALPS system became operational in September 2014. It is very similar to the first ALPS, with the exception that ferric hydroxide coprecipitation was removed and that there were two additional sorbent beds (TEPCO Press Conference handout from September 11, 2014). Both Energy Solutions ALPS systems have three parallel lines. A third ALPS system, constructed by Hitachi, Japan, was commissioned in October 2014. It is based on cesium and strontium removal with five silicotitanate beds. Furthermore, instead of coprecipitation this system uses four filters in front of silicotitanate beds $(6,7)$. Additional information on these filters is not available. The silicotitanate used in this system seems to be UOP CST treated with dilute $\mathrm{NaOH}$ solution.

Figure 8. Flow diagram of the first ALPS (Advanced Liquid Processing System) commissioned in March 2013 at the Fukushima Daiichi plant to purify reverse osmosis retentates. (http://www.tepco.co.jp/en/decommision/planaction/alps/index-e.html). 
A further system to purify reverse osmosis is the Kurion mobile system (Fig. 9), which was operational in December 2014. Its purpose was to reduce the radiostrontium concentration by a factor of 10 to 1000 in the reverse osmosis retentates prior to their treatment in ALPS. This system has stainless steel filters (SS filters) to remove coarse particles, an ultafiltration unit (UF) to remove colloidal matter, and adsorption beds. The sorbent used in these beds is not known.

Figure 9. The Kurion mobile system to reduce radiostrontium concentrations in the Fukushima Daiichi reverse osmosis retentates prior to their treatment in ALPS. From TEPCO Press Conference handout from October 2, 2014.

As approximately half of the water going to reverse osmosis is recycled back to reactors for cooling, we may assume that the salinity of the reverse osmosis retentate is doubled from that in the solution going to the SARRY/Kurion systems. As seen in Fig. 6, the salinity has greatly decreased during the seven years. The chloride concentration in 2011 was 5300 ppm; the value was 1100 ppm in 2012, 620 in 2013, and 370 in later years (all average values). Even the latest chloride concentrations were fairly high compared to typical ground water concentration. In the sea water that was injected into the reactors in the early phases, the chloride and sodium ions formed $73 \%$ of the total ionic strength of $0.7 \mathrm{~mol} / \mathrm{L}$. This is not the same for groundwaters, which are the source of ions excluding the very early phases. We are not aware of the groundwater composition at the Fukushima Daiichi area. However, based on general knowledge of groundwaters the concentration of sulfate is on the same level as that of chloride. Furthermore, potassium, calcium, and magnesium concentrations may also be at the same level as that of sodium. The variation of their concentrations and mutual ratios vary, however, very much from case to another (8). Sylvester at al. (4) reported that the reverse osmosis retentates have a $\mathrm{pH}$ close to neutral and have high total dissolved solids contents up to $20 \mathrm{~g} / \mathrm{L}$. This very high value refers to the very early phases of the separation when there was still sea water in the system. 
By the end of 2017, the ALPS systems had treated altogether $842000 \mathrm{~m}^{3}$ of water coming from the reverse osmosis (RO) system. ALPS 1 performed 52\% of the treatment, ALPS 2 performed 35\%, and only $13 \%$ was performed by ALPS 3 . The last system, ALPS 3 (initially referred to as "high performance ALPS") was in operation only for 1.5 years, suggesting that it did not work. Since March 2016 it has been completely out of operation. In the test run of the ALPS 3 system in $2015,{ }^{90}$ Sr was removed from $82000 \mathrm{~m}^{3}$ of reverse osmosis retentates with a decontamination factor between 100 and 1000; these values were far below than those obtained with ALPS systems using sodium titanate (see next section). A probable reason for the failure is that evaluation tests were performed with a sea water simulant containing salts corresponding to their actual concentration in sea water (6). This procedure probably underestimates the effects of calcium, magnesium, and potassium which are, unlike in sea water, important ions in groundwater that are the source of ions after the very early phase. In fact, these ions compete much more strongly with cesium/strontium than sodium ions (9).

The performance of the ALPS systems in radionuclide removal has not been well reported. Table 5 provides information on the performance of ALPS 1 in March 2013, the only operational system at the time. The results are likely from preliminary tests, since ALPS 1 started operation in March 2013. At that time, already 37 out 62 target nuclides were under their limits of detection. After purification, all other radionuclides were below the required values to allow discharge into the sea. As stated earlier, the coprecipitation pretreatment removed $95 \%$ of radioactivity. This does not apply to the radionuclides that do not precipitate as hydroxides or carbonates (Cs, I, Tc, and probably $\mathrm{Ru}$ and $\mathrm{Sb}$ ). We may thus assume that the decontamination factor reported in Table 5 for these nuclides represent those for the sorption phase. For the radionuclides that form hydroxides and carbonates ( $\mathrm{Co}, \mathrm{Ni}, \mathrm{Sr}, \mathrm{Pu}, \mathrm{Am}, \mathrm{Cm}$ ), the decontamination factor of the sorption phase is lower than that reported in Table 5 by a factor of 20 if we assume that $95 \%$ of all these elements were removed in the pretreatment phase. The decontamination factor of SrTreat for ${ }^{90} \mathrm{Sr}$ sorption is 60000000 , which is an enormously high value. For CsTreat, the decontamination factor would be the same as reported in Table 4 (56 000). In the full-scale test run it was observed that the ALPS 1 system did not remove ${ }^{60} \mathrm{Co},{ }^{106} \mathrm{Ru},{ }^{125} \mathrm{Sb}$, and ${ }^{129}$ I sufficiently to reach the required activity level. This problem was solved by adding two more sorbent beds to ALPS 2 and changing sorbents (TEPCO Press Conference handout from July 31,2014$)$. It was not revealed which sorbent(s) was changed. The waters already 
treated with ALPS 1 with insufficient removal of ${ }^{60} \mathrm{Co},{ }^{106} \mathrm{Ru},{ }^{125} \mathrm{Sb}$, and ${ }^{129}$ I were retreated with ALPS 2.

Table 5. Radionuclide concentrations $(\mathrm{Bq} / \mathrm{L})$ in reverse osmosis retentate, decontamination factors obtained with ALPS 1, and the factors by which the concentrations are below the required level. The values in the two last columns are minimum values, since all the radionuclide concentrations were below detection limits. Minimum values were calculated using the detection limits. Data extracted from TEPCO Press Conference handout from March 29, 2013.

While the performance of the Kurion mobile strontium removal system has not been reported, the target was to achieve a 10 to 1000 -fold reduction in the ${ }^{90} \mathrm{Sr}$ concentration. The Kurion system produces additional secondary solid waste but due to lack of information it is unclear what benefit $f$ it provides in final purification of the waste effluents.

The secondary solid waste from the ALPS systems, sorbents, and precipitation sludges are stored in High Integrity Containers (HIC). The sorbents from the Kurion Sr-removal system are probably also stored in HICs, which are made of polyethylene and have a volume of $3.8 \mathrm{~m}^{3}$ (diameter $1.6 \mathrm{~m}$, height $1.9 \mathrm{~m}$ ). In June 2012 (TEPCO Press Conference handout from June 26, 2012) it was estimated that 500 containers are generated annually ( 50 from sorbents and 450 from sludge). The HICs are stored in concrete containers of approximately $20 \mathrm{~m}^{3}$ (TEPCO Press Conference handout from March 29, 2013); two HICs are stored in each container. At the end of 2017 there were altogether 2621 of these containers. The total volume of the containers is approximately $50000 \mathrm{~m}^{3}$ and the total volume of the HICs approximately $20000 \mathrm{~m}^{3}$. It is not known what fraction of these volumes are generated by the Kurion mobile strontium removal system's spent sorbents. These figures, however, show that the volume reduction factor (volume reduction factor $=$ volume of produced solid waste divided by the volume of treated waste effluent) of the ALPS and Kurion strontium removal systems in total is approximately 20 (based on the volume of the containers) and 50 (based on the volume of HICs). These values are evidently not very high, which means that very large amounts of secondary solid waste have been generated and are still being generated.

In 2015, TEPCO reported that all other reverse osmosis retentates will be treated by May 2015 but not the highly saline $20000 \mathrm{~m}^{3}$ generated in the early phases of the accident due to injection of sea 
water into the reactors. In February 2016 this volume decreased to $11.000 \mathrm{~m}^{3}$ and has remained the same since.

The nearly million cubic meters of waters purified with the ALPS systems are stored onsite in 650 tanks each with $1000 \mathrm{~m}^{3}$ of volume. The waters are still stored in the tanks since they contain tritium, which the ALPS systems cannot remove. Tritium $\left({ }^{3} \mathrm{H}\right)$ is bound to water as ${ }^{3} \mathrm{HHO}$ and is therefore not separable by any reasonable method. Efforts to remove tritium by electrolytic enrichment processes have not lead to practical applications due to extremely high costs. The tritium levels in the effluents are fairly high $\left(1 \times 10^{6}\right.$ to $\left.5 \times 10^{6} \mathrm{~Bq} / \mathrm{L}\right)$. Regulations require levels below $6 \times 10^{4} \mathrm{~Bq} / \mathrm{L}$; the solution should thus be diluted by a factor of 50 to 100 prior to release into sea. The reason for not doing this is probably not technical or based on radiation safety but is of a political nature.

PREPARATION, STRUCTURE, AND ION-EXCHANGE PROPERTIES OF THE ION EXCHANGERS USED AT THE FUKUSHIMA DAIICHI NUCLEAR PLANT FOR CESIUM AND STRONTIUM REMOVAL

The preparation, structure, and ion-exchange properties of the four types of inorganic ion exchangers used at the Fukushima Daiichi nuclear plant to remove radiocesium and radiostrontium from waste effluents are reviewed in the following sections. These exchangers are zeolites, transition metal hexacyanoferrates, titanates, and silicotitanates. In addition to general information, examples of their use in nuclear waste treatment processes outside of Fukushima are given.

\section{Zeolites}

There are a number of naturally occurring and synthetic zeolite minerals. They all are microporous crystalline aluminosilicates with a general formula of $\mathrm{M}_{\mathrm{y} / \mathrm{z}}\left[\left(\mathrm{SiO}_{2}\right)_{\times}\left(\mathrm{AlO}_{2}\right)_{\mathrm{y}}\right] \times \mathrm{nH}_{2} \mathrm{O}$, where $\mathrm{M}$ is an alkali metal or alkaline earth metal with a charge of $+z$. The framework consists of $\mathrm{SiO}_{4}$ and $\mathrm{AlO}_{4}$ tetrahedra, which share all four oxygens. More than a hundred different zeolite structures are known. Due to the replacement of tetravalent $\mathrm{Si}^{4+}$ with trivalent $\mathrm{Al}^{3+}$, the framework carries an electric charge that is balanced by alkaline or alkaline earth metal ions. The aluminosiliacate 
structure in zeolites forms a rigid three-dimensional framework containing channels and cavities where the alkaline and alkaline earth metal ions and water molecules are located (Fig. 10). These metal ions are mobile and exchangeable to ions in solutions in contact with zeolites. (10).

The two factors affecting the selectivity towards ions in zeolites are the dimensions of the cavities and the Si:Al ratio of the framework. For example, chabazite has pore openings of $0.37 \times 0.42 \mathrm{~nm}$ while mordenite has much larger pores of $0.67 \times 0.70 \mathrm{~nm}$. In a single zeolite there can be channels/cavities of different sizes that accommodate ions of different size. In general, the size of the channels/cavities affects the selectivity in the so-called ion sieve way; ions of size larger than the channel/cavity are excluded. Only ions and molecules that fit into the channels/cavities may be taken up. However, ions much smaller than the size of channel/cavity are not effectively retained due to their high mobility. In general, alkali metals and alkaline earth metal ions with increasing atomic number are more effectively retained since the size of hydrated ions in both series decreases when going from light to heavy elements. The selectivity may, however, become reversed if the zeolite is able to strip water molecules from the hydrated ions, as the sizes of the nonhydrated ions in both series develop in the opposite way to the hydrated ones. i.e. their size increases with atomic number. The stripping of water molecules is only possible when the framework charge of the zeolite is sufficiently high. In turn, the framework charge is dependent on the Si:Al ratio; lower ratios are accompanied with higher charges. In naturally occurring zeolite minerals, the Si:Al ratio varies in a rather large range of 1 to 6 . In synthetic zeolites the ratio may be much higher (even 20 in the case of zeolite ZSM-5). The Si:Al ratio also affects the selectivity such that zeolites with a high Si:Al ratio (low framework charge) prefer univalent ions (such as $\mathrm{Cs}^{+}$) while those with a low ratio (high framework charge) prefer divalent ions (such as $\mathrm{Sr}^{2+}$ ). Furthermore, since the replacement of Si with Al creates the framework charge, the ion-exchange capacity is proportional to Si:Al ratio; lower ratios have higher capacity. In zeolite A, which has the highest Si:Al ratio of 1 , the theoretical ion exchange capacity is as high as $5.3 \mathrm{meq} / \mathrm{g}$. On the other hand, the corresponding capacity for the high Si:Al ratio zeolite ZSM-5 is only $2.1 \mathrm{meq} / \mathrm{g}$.

Figure 10. Framework structure of chabazite (http://www.ch.ic.ac.uk/nicholson/tg_main.html).

Herschelite, the zeolite used at the Fukushima Daiichi plant, is a specific type of chabazite with a formula of $\mathrm{M}_{2 / 2} \mathrm{Al}_{2} \mathrm{Si}_{4} \mathrm{O}_{12} \times 6 \mathrm{H}_{2} \mathrm{O}$. The exchangeable ion $\mathrm{M}$ is typically $\mathrm{Na}^{+}, \mathrm{K}^{+}$, or $\mathrm{Ca}^{2+}$ and in natural conditions the zeolite has all these ions, with proportions depending on the groundwater 
composition. Chabazite has an intermediate Si:Al ratio of 2 and a theoretical ion exchange capacity of $3.8 \mathrm{meq} / \mathrm{g}$.

Compared with conventional organic polystyrene sulfonic acid resins, zeolites offer higher ion selectivities. For example, the selectivity coefficient (mass action quotient) for the cesium exchange on sodium-form organic resin is only less than 10 (11), while the corresponding value for mordenite is as high as 450 (12). As described later, much higher values are obtainable with silicotitanates and particularly with hexacyanoferrates.

The largest zeolite utilization in nuclear waste effluent treatment takes place at the Sellafield nuclear plant in the UK where radiocesium and radiostrontium are removed from fuel storage pond waters with 10- $\mathrm{m}^{3}$ clinoptilolite columns (13). The SIXEP (Site lon Exchange Effluent Plant) started operation in 1985 and has to date produced some $700 \mathrm{~m}^{3}$ of spent ion exchanger ( $20 \mathrm{~m}^{3}$ annually) (14). The plant processes daily some $4000 \mathrm{~m}^{3}$ of liquid; the annual volume is well above $1000000 \mathrm{~m}^{3}$. The processing capacity is thus tens of thousands of litres of liquid per kg of exchanger. This high processing capacity is obtainable due to the very low ionic strength of the solution.

Similar remedial action as at the Fukushima Daiichi, but at a much smaller scale, was taken at the Three Mile Island nuclear power plant, USA, where radiocesium and radiostrontium were removed from high-active waste solution generated in the meltdown accident in 1979. Cesium was effectively removed with chabazite (IONSIV IE-95) and strontium with zeolite A (IONSIV A-51), both presently produced by UOP, USA. Almost $3000 \mathrm{~m}^{3}$ of waste was purified from $5 \mathrm{PBq}$ of radiocesium and radiostrontium with ten 230 -L zeolite columns. The volume reduction factor was thus 1200 and the decontamination factor was approximately $10000(15,16)$. As in the case of SIXEP, the ionic strength here was also rather low (sodium concentration 50-60 mol/L). Zeolite A prefers divalent ions $\left(\mathrm{Sr}^{2+}\right.$ ) since it has a low Si:Al ratio (1) while chabazite is more selective to univalent ions $\left(\mathrm{Cs}^{2+}\right)$ due to its higher Si:Al ratio of 2 .

\section{Hexacyanoferrates}

Cesium ions do not effectively sorb on non-specific exchangers (such as organic resins) due to their low charge and large size. There are, however, a few selective sorbents for cesium; these are ammonium phosphomolybdate (AMP), silicotitanates, zeolites, clay and mica minerals, and transition metal hexacyanoferrates, the latter being the most selective. CsTreat, the 
hexacyanoferrate product manufactured by Fortum utilized at the Fukushima Daiichi plant was the first to be manufactured at industrial scale for nuclear waste purifications $(17,18)$. It was used for first time in 1991 in a full-scale process at the Loviisa nuclear power plant, Finland, where CsTreat has processed $>1000 \mathrm{~m}^{3}$ of highly saline waste containing 2 to $3 \mathrm{M}$ of sodium ions and 0.05 to 0.3 $\mathrm{M}$ of potassium ions. The processing capacity was very high (11 $000 \mathrm{~L} / \mathrm{kg})$ and the cesium decontamination factor well above 1000 (19). From 1991 onwards, CsTreat has been utilized at tens of nuclear plants worldwide, for example in the removal of radiocesium from the $\mathrm{Na} / \mathrm{K}$ coolant in the remediation of Dounreay fast reactor plant in the UK $(20,21)$.

The oldest known transition metal hexacyanoferrate is Prussian Blue $\mathrm{Fe}_{4}\left[\mathrm{Fe}(\mathrm{CN})_{6}\right]_{3}$, which is used as a colour pigment and also as an agent to remove radiocesium from contaminated animals and milk. The hexacyanoferrate products used as cesium sorbents for analytical and waste purification purposes are typically the alkali metal salts of $\mathrm{Co}, \mathrm{Ni}, \mathrm{Zn}$, and $\mathrm{Cu}\left(\mathrm{M}^{2+}\right)$ hexacyanoferrates. They are rather easy to prepare; mixing of $\mathrm{M}^{2+}\left(\mathrm{NO}_{3}\right)_{2}$ and $\mathrm{K}_{4} \mathrm{Fe}(\mathrm{CN})_{6}$ solutions results in the formation of a $\mathrm{K}_{2} \mathrm{MFe}(\mathrm{CN})_{6}$ product (formula for the stoichiometric product, the fraction of $\mathrm{K}$ may vary). The product is colloidal dispersion and granulation is needed for utilization as an ion-exchange product for waste effluent treatment in column mode. These products have a cubic structure in which $\mathrm{M}$ and Fe are in the corners of the cubes and the cyanide groups between them are on the cube edges (Fig. 11). Alkali metals are located in the middle of the cubes. The unit cell of $\mathrm{K}_{2} \mathrm{CoFe}(\mathrm{CN})_{6}$ contains eight of these elementary cubes and $a$ parameter of the cube is $1.006 \mathrm{~nm}$ (22). The cesium compound $\mathrm{Cs}_{2} \mathrm{CoFe}(\mathrm{CN})_{6}$ is isomorphous to the potassium compound with a slightly greater $a$ parameter of $1.030 \mathrm{~nm}(23)$.

Figure 11. Optimized unit cell of $\mathrm{K}_{2} \mathrm{CoFe}(\mathrm{CN})_{6}(\mathrm{a})$ and the same with van der Waals spheres (b).

Lehto et al. (24) have shown that not all potassium ions in $\mathrm{K}_{2} \mathrm{CoFe}(\mathrm{CN})_{6}$ are exchangeable but only those at the surfaces of crystals of 10 to $40 \mathrm{~nm}$ size. The cesium ion exchange capacity is therefore clearly below that of the theoretical capacity ( $23 \%$ of $5.73 \mathrm{meq} / \mathrm{q}$ for the stoichiometric compound). For a non-stoichiometric product with potassium between 1.2 to 2 per unit formula, the ion cesium exchange capacity is even lower (minimum 0.5-0.6 meq/g observed for a product with potassium 1.5-1.6 per unit formula). The stoichiometric compound was shown to be very soluble and is thus not suitable as an ion exchanger. However, the non-stoichiometric products (with potassium 1.21.6 per unit formula) are very stable and exhibit only 1 to $2 \%$ solubility of that of the stoichiometric compound. The reason for the very high selectivity of potassium cobalt hexacyanoferrate is 
unknown. It seems reasonable to assume that the window to the elementary cubes on the crystal surfaces are larger than those in the inner parts, since cesium does not go further from the surface cube. Since cesium is essentially irreversibly taken up (25), it is possible that once potassium is replaced by cesium ions the window contracts trapping the cesium into the cube.

\section{Silicotitanates}

Several silicotitanates with varying structures and compositions have been prepared by hydrothermal syntheses $(26,27)$. These have three-dimensional frameworks with cavities and tunnels but products with layered structures have also been developed. The coordination of titanium varies from tetrahedral $\mathrm{TiO}_{4}$ to octahedral $\mathrm{TiO}_{6} ; \mathrm{TiO}_{5}$ coordination has also been observed. From the perspective of nuclear waste effluent purification, the most important of these is the socalled crystalline silicotitanate (CST). CST has the ideal formula of $\mathrm{Na}_{2} \mathrm{Ti}_{2} \mathrm{O}_{3} \mathrm{SiO}_{4} \times 2 \mathrm{H}_{2} \mathrm{O}$ and was developed at Texas A\&M University and the Sandia National Laboratories (28). It is a framework compound consisting of cubane-like $\mathrm{Ti}_{4} \mathrm{O}_{4}$ units linked together by silicate groups in the way that tunnels are formed (Fig. 12). Half of the sodium ions, all exchangeable, are located in the tunnels while the other half lies in the framework between silicate groups (29). Cesium is exchanged only to the tunnel sites and there they occupy only half of them, thus only one fourth of sodium ions are exchangeable for cesium (30). According to Clearfield, "The reason for the high selectivity of the titanosilicate for cesium apparently results from its coordination in the tunnels. The bond distances are almost the sum of the ionic radii and eight framework oxygens form a highly symmetrical coordination sphere almost like a crown ether complex." (31).

For nuclear waste effluent treatment processes, CST has been manufactured by UOP, USA under the trademark IONSIV-IE911 and later as IONSIV R9120. In 2001, IONSIV-IE911 was reported to have a zirconium oxide binder (32). CST has proved to be an efficient exchanger for cesium ions and tolerates rather high concentrations of competing sodium ions and high alkalinities (28). Potassium, however, impairs the cesium sorption strongly $(9,30)$. The loading capacity of CST is $1.36 \mathrm{meq} / \mathrm{g}(33)$. In addition to cesium, silicotitanate has been reported to take up strontium as well, but not as efficiently as cesium (34). As the ${ }^{90} \mathrm{Sr}$ distribution coefficient in solution containing only strontium at trace levels was about $24000 \mathrm{ml} / \mathrm{g}$, its value decreased to about $6000 \mathrm{ml} / \mathrm{g}$ in a waste simulant containing $0.6 \mathrm{M} \mathrm{NaOH}$ and $5.1 \mathrm{M} \mathrm{NaNO}_{3}$. In actual waste, the distribution coefficient further 
decreased to $4000 \mathrm{ml} / \mathrm{g}$. In comparison, the cesium distribution coefficient in the same waste was $17500 \mathrm{ml} / \mathrm{g}$. In tests with DOE Hanford site, USA, waste effluents CST has been reported to be superior cesium sorbent compared to organic resorcinol-formaldehyde and phenol-formaldehyde resins, as well as compared to Superlig 644 solvent extraction agent and the zeolite lonsiv-96. In 5M Na solution containing $0.5 \mathrm{mM}$ of Cs the distribution coefficient of cesium was above $50000 \mathrm{ml} / \mathrm{g}$ at $\mathrm{pH}$ range 2-8 and decreased gradually to about $1000 \mathrm{ml} / \mathrm{g}$ at $\mathrm{pH} 13$ (35).

Commercial CST, namely UOP IONSIV R9120, has not been reported to have been utilized in full scale in sites other than the Fukushima Daiichi plant. However, it has been tested for several US DOE site waste effluents (36) and a system Tank Closure Cesium Removal (TCCR) utilizing CST in cesium removal at the Savannah River Plant, USA, has been reported to be operational by the end of 2018 (37).

Figure 12. Crystal structure of $\mathrm{Na}_{2} \mathrm{Ti}_{2} \mathrm{O}_{3} \mathrm{SiO}_{4} \times 2 \mathrm{H}_{2} \mathrm{O}(31)$.

Titanates and hydrous titanium oxides

Hydrous titanium oxides $\left(\mathrm{TiO}_{2-x}(\mathrm{OH})_{\times} \times \mathrm{nH}_{2} \mathrm{O}\right)$ can be prepared by hydrolysis of titanium-bearing solutions, such as $\mathrm{TiCl}_{4}$. The products prepared at low temperatures are amorphous. In case an alkali metal (such as sodium) is present in the synthesis, it is attached to the hydroxyl group $\mathrm{M}-\mathrm{OH}$ at $\mathrm{pH}$ values above the isoelectric point (approximately $\mathrm{pH} 4$ for titanium oxide). Hydrous oxides are amphoteric, taking up anions below the isoelectric point on protonated hydroxyl sites $\left(\mathrm{M}-\mathrm{OH}_{2}{ }^{+}\right)$and cations above it on dissociated hydroxyl sites (M-O). The sodium ions attached to hydroxyl groups are exchangeable and typically highly selective to heavier alkaline earth metal ions $\left(\mathrm{Ca}^{2+}, \mathrm{Sr}^{2+}, \mathrm{Ba}^{2+}\right.$, $\left.\mathrm{Ra}^{2+}\right)$. Hydrous titanium oxides in sodium form are typically called sodium titanates. Crystalline sodium titanates can be obtained by heating sodium-form hydrous titanium oxides and by solidstate synthesis at elevated temperatures from $\mathrm{TiO}_{2}$ and $\mathrm{Na}_{2} \mathrm{O} / \mathrm{Na}_{2} \mathrm{CO}_{3}$. Furthermore, they are obtainable from hydrothermal synthesis in closed vessels at high pressure. To prevent immediate hydrolysis of titanium and to obtain a homogenous precursor for hydrothermal synthesis, the solgel method is utilized using alcohol-based starting materials, such as titanium alcoxides and sodium 
hydroxide dissolved in alcohol. Crystalline sodium titanates belong to two series $\left(\mathrm{Na}_{2} \mathrm{Ti}_{n} \mathrm{O}_{2 n+1}\right.$ and $\mathrm{Na}_{4} \mathrm{Ti}_{n} \mathrm{O}_{2 n+2}$ ). In these compounds the framework is constructed of $\mathrm{TiO}_{6}$-octahedra, which share oxygens in various ways. Part of the titanates form structures where the sodium ions are located in the channels of the rigid three-dimensional framework, while the others form layered compounds with sodium ions between the layers (Fig. 13). Layered titanates can expand or shrink depending on the type of ion between the layers and especially on the water content between the layers (38).

Figure 13. Examples of a layered titanate (left) and a cavity-type titanate (right).

A new sodium titanate, $\mathrm{Na}_{4} \mathrm{Ti}_{9} \mathrm{O}_{20} \times \mathrm{nH}_{2} \mathrm{O}$, was synthesized by Clearfield and Lehto (38) by hydrothermal synthesis at $280^{\circ} \mathrm{C}$ and below from titanium isopropoxide and sodium hydroxide. It is a layered compound with an ion exchange capacity of $4.74 \mathrm{meq} / \mathrm{g}$. The distance between the layers of the fully hydrated product is $1.00 \mathrm{~nm}$; the nonhydrated product has an interlayer distance of 0.69 $\mathrm{nm}$. In between there is a semihydrated product with an interlayer distance of $0.86 \mathrm{~nm}$. All sodium ions are exchangeable and strontium exchange on $\mathrm{Na}_{4} \mathrm{Ti}_{9} \mathrm{O}_{20}$ takes place in an equivalent manner, namely each $\mathrm{Sr}^{2+}$ ion replaces two $\mathrm{Na}^{+}$ions (39).

Sodium titanates used for nuclear waste treatment are typically amorphous products produced at low temperatures from room temperature to boiling mixtures. This also applies to SrTreat ${ }^{\circledR}$, the sodium titanate used in ALPS for strontium removal. SrTreat has been developed in collaboration with the Radiochemistry Unit of the University of Helsinki and the Fortum company, Finland, and is being manufactured in granular form by the latter $(5,40)$. This product is a highly efficient ion exchanger for the removal of radiostrontium from alkaline solutions with $\mathrm{pH}>9$. As the product has practically no preference of strontium over calcium, the major interfering ion is calcium. However, the selectivity over alkali metals, typically present in nuclear waste effluents, is very high. The distribution coefficient of trace strontium remains at a very high level (>100 $000 \mathrm{ml} / \mathrm{g}$ ) even at sodium and potassium concentrations $>1 \mathrm{~mol} / \mathrm{L}(40)$. SrTreat was used for the first time in industrialscale process in 1996 when it was utilized to remove radiostrontium from process waters at the Russian civil nuclear fleet base in Murmansk. Sixty cubic meters of waste effluent containing $0.4 \mathrm{~g} / \mathrm{L}$ of salts was purified with a single $12-\mathrm{L}$ column. The processing capacity was $5700 \mathrm{~L} / \mathrm{kg}$ while the 
decontamination factor was as high as 7600 (41). SrTreat has subsequently been used at several nuclear plants, including the Japan Atomic Energy Research Institute (JAERI), Japan (21).

A sodium titanate, monosodium titanate $\mathrm{NaTi}_{2} \mathrm{O}_{5} \mathrm{H}(\mathrm{MST})$, for radiostrontium and actinides removal was already reported in 1976 by Lynch et al. (42) from Sandia National Laboratories, USA. This product is produced by a sol-gel method from titanium tetraisopropoxide and sodium methoxide resulting in the formation of powder-form material. This material has been used for radiostrontium removal from high-active waste effluents at the Savannah River plant, USA (43). Instead of more efficient column operation, the process uses in-tank batch operation where an MST dispersion slurry is poured into a waste tank and mixed for 12 hours after which the solids are filtered and stored for solidification into borosilicate glass. Due to the batch operation mode, the separation performance is only modest. From alkaline waste containing 5 to $6 \mathrm{~mol} / \mathrm{L}$ sodium, the decontamination factor was only 2 to 5 for ${ }^{90} \mathrm{Sr}$ and 3 to 6 for Pu when using 0.4 to $0.5 \mathrm{~g} / \mathrm{L}$ of MST (processing capacity 2000$2500 \mathrm{~L} / \mathrm{kg}$ ) (44). From a similar waste effluent at the JAERI, Fortum SrTreat removed radiostrontium with a decontamination factor of 1000 to 3000 up to 1000 bed volumes of treated waste (45). This clearly demonstrates the superiority of column processes over batch ones.

A potassium titanate, potassium bitinate $\mathrm{K}_{2} \mathrm{Ti}_{2} \mathrm{O}_{5}$, has been developed by Kurita Water Industries and Tohoku University, Japan, for the radiostrontium removal in the ALPS system at the Fukushima Daiichi plant (46). The product is granulated by using a clay binder up to $23 \mathrm{w}-\%$, which lowers the strontium distribution coefficient by a factor of approximately 10. From a 0.01-mM Sr solution containing $430 \mathrm{mM} \mathrm{Na}, 0.3 \mathrm{mM} \mathrm{Ca}$, and $0.04 \mathrm{mM} \mathrm{Mg}$, the $50 \%$ strontium breakthrough occurred at approximately $2000 \mathrm{BV}$, which corresponds to a distribution coefficient value of approximately 4000 $\mathrm{ml} / \mathrm{g}$.

\section{THE GREAT IMPORTANCE OF SELECTIVITY}

Inorganic ion exchangers possess several advantageous properties over organic resins, such as good thermal and radiation resistance. The most important benefit, however, is the high selectivity offered by many inorganic materials. In nuclear waste effluents, the chemical concentrations of radionuclides are typically very low; only in high-active waste solutions are such concentrations at the macro level. In Fukushima Daiichi, in the waste effluents the chemical concentration of ${ }^{137} \mathrm{Cs}$ in the early years was 2 to $4 \mu \mathrm{mol} / \mathrm{L}$ and the concentration of ${ }^{90} \mathrm{Sr}$ was one tenth of ${ }^{137} \mathrm{Cs}$. After a few 
years, the ${ }^{137} \mathrm{Cs}$ concentration had decreased to a few tens of nanomoles per litre. At the same time, other chemically very similar elements $(\mathrm{Na}, \mathrm{K}, \mathrm{Ca}$, and $\mathrm{Mg})$ were present at much higher concentrations, from several millimoles per litre up to hundreds. Thus, highly selective ion exchangers are needed to separate radionuclides from solutions containing similar elements at several orders of magnitude higher concentrations. An extreme example of the required high selectivity is the purification of evaporator concentrates at the Loviisa nuclear power plant in Finland. In 1991 the activity of ${ }^{137} \mathrm{Cs}$ was $0.4 \mathrm{MBq} / \mathrm{L}$, which corresponds to a chemical concentration below $1 \mathrm{nmol} / \mathrm{L}$. At the same time, the solution contained sodium at 2 to $3 \mathrm{~mol} / \mathrm{L}$, or over $10^{9}$-fold excess compared to cesium. Despite this, CsTreat could remove ${ }^{137} \mathrm{Cs}$ from 11000 litres of waste with $1 \mathrm{~kg}$ of exchanger, yielding a decontamination factor well above 1000 (19). This clearly demonstrates the great benefit achievable with selective materials, in this case a superselective material. Selectivity brings the following two major benefits:

- Processing capacity (i.e., the volume of waste effluent purified per unit mass of ion exchanger) is higher the more selective the material is towards the target ion. This means that the volume of secondary waste, i.e. spent ion exchanger, is lower the higher the processing capacity. This in turn brings savings in waste disposal costs. In most countries the disposal costs of nuclear waste are very high since the waste is disposed of in geological repositories, the construction of which is very expensive. Thus, the typically high prices of novel selective ion-exchange media are not of great importance if they bring great savings in disposal costs.

- Decontamination factors obtained with selective media are typically higher than with less selective media. This may enable discharge of purified liquid into open waters if the achieved activity level is below required exemption limits. This could at least enable classification of waste effluent into a lower activity level category that would require less demanding and less expensive treatment and disposal methods.

Selectivity is typically expressed as a distribution coefficient $\left(K_{d}\right)$. For example, for a reaction of cesium for sodium exchange in exchanger $\mathrm{X}$ :

$$
\mathrm{XNa}+\mathrm{Cs}^{+} \leftarrow \rightarrow \mathrm{XCs}+\mathrm{Na}^{+}
$$

the distribution coefficient is the ratio of the cesium concentration in the exchanger $\left([\mathrm{Cs}]_{\mathrm{x}}\right)$ to that in the solution phase $\left([\mathrm{Cs}]_{s}\right)$ : 


$$
K_{d}=\frac{\mid C s\rfloor_{x}}{\lfloor C s\rfloor_{s}}
$$

From a waste-processing perspective, $K_{d}$ is important since it equals the processing capacity, which is the volume of waste effluent that can be purified per unit mass of ion exchanger. For example, if the $K_{d}$ is $60 \mathrm{ml} / \mathrm{g}(\mathrm{L} / \mathrm{kg})$, the $50 \%$ breakthrough occurs at 60 litres volume when $1 \mathrm{~kg}$ exchanger bed is used (Figure 14, left). When the $K_{d}$ is 100 -fold higher, the $50 \%$ breakthrough accordingly occurs at a 100-fold higher volume (Figure 14, right). It is evident that in waste treatment processes the beds are not run up to $50 \%$ breakthrough but to a lower value (for example $1 \%$ ). Nevertheless, the processing capacities thus observed are still proportional to the $K_{d}$ values. Kinetics and processing rates naturally affect the volume where $1 \%$ breakthrough is observed. This is not discussed here as our focus is on selectivity.

Figure 14. Hypothetical column breakthrough curves of two exchangers with $\mathrm{K}_{d}$ values of $60 \mathrm{ml} / \mathrm{g}$ (left) and $6000 \mathrm{ml} / \mathrm{g}$ (right). Exchanger bed mass $1 \mathrm{~kg}$.

The distribution coefficient is conditional and depends on many factors, in particular $\mathrm{pH}$ and the concentrations of the ions involved with the reactions. Exchangers with hydroxyl groups as their functional groups $(\mathrm{M}-\mathrm{OH}$ ) are affected by the $\mathrm{pH}$ in the way that the $\mathrm{M}-\mathrm{OH}$ group dissociates at $\mathrm{pH}$ values above the isoelectric point of the oxide to $\mathrm{M}^{-} \mathrm{O}^{-}$, which is capable of taking up cations. The $\mathrm{pH}$ value where this occurs depends on the nature of the central metal $\mathrm{M}$. The higher the metal charge and the smaller its size, the greater is the metal charge density. Metals with high charge density are the most acidic and their hydroxyl groups dissociate accordingly at lower $\mathrm{pH}$. In silica $\left(\mathrm{SiO}_{2}\right)$ dissociation, cation exchange thus takes place already at $\mathrm{pH}>2$. For example, $\mathrm{Al}_{2} \mathrm{O}_{3}$ has a low charge density and thus its cation exchange ability starts only at pH 8 . The isoeletric point of titanium oxide is between silica and aluminum oxide, close to 4 .

Ion exchange based on electrostatic interaction (outer-sphere complexation) is the uptake mechanism for the low charge and large size of the sorbing ion, particularly alkaline and alkaline earth metal ions (including cesium and strontium). With increasing charge and decreasing size of the sorbing metal (i.e., hydrolysable metals such as $\mathrm{Ni}, \mathrm{Co}, \mathrm{Po}, \mathrm{Pb}, \mathrm{Pu}$, and $\mathrm{Am}$ ), the bond between the sorbing metal and the oxygen of the $\mathrm{M}-\mathrm{OH}$ group becomes more covalent in nature. This sorption involving formation of a chemical bond is called surface complexation. With these metals, the $\mathrm{pH}$ where the sorption starts is, however, not dependent only on the surface charge of the oxide 
but also on the hydrolysis strength of the metal. The bonding strength on a specific oxide is directly proportional to the hydrolysis constant of the sorbing ion. Thus $\mathrm{Pu}^{4+}$ sorbs much more strongly than $\mathrm{Ni}^{2+}$, for example.

In case the negative charge responsible for cation exchange arises from a framework charge instead of surface hydroxyl groups, the sorption of metal cations is not dependent on $\mathrm{pH}$. These types of exchangers include mica and clay minerals, zeolites, and hexacyanoferrates, for which the $\mathrm{pH}$ where cation exchange occurs at lower values than in the case of oxide or hydroxide exchangers or minerals. However, even these framework-charge bearing exchangers or minerals have hydroxyl groups at their particle surfaces due to discontinuation of the framework structure. Thus, there are several types of ion-exchange sites in most if not all inorganic ion exchangers or minerals. The smaller the particle size the larger is the fraction of surface hydroxyl sites.

Figure 15. Hypothetical sorption of $\mathrm{M}^{+}$on three exchangers of varying acidity. Model curves for $\mathrm{SiO}_{2}$ (left), $\mathrm{TiO}_{2}$ (middle), and $\mathrm{Al}_{2} \mathrm{O}_{3}$ (right).

In addition to $\mathrm{pH}$, the distribution coefficient of radionuclides is dependent on competing macro ions in solution, such as $\mathrm{Na}^{+}$in the case of $\mathrm{Cs}^{+}$exchange. It is evident from Eq. 1 that the greater the presence of sodium ions, the more the equilibrium moves to the left side and thus the $K_{d}$ decreases. Mathematically, we can derive the relation in the following way. We first define a new term, the selectivity coefficient $\mathrm{k}_{\mathrm{cs} / \mathrm{Na}}$, which is the mass action quotient for the reaction (1).

$$
k_{C s / N a}=\frac{\lfloor C s\rfloor_{x}\lfloor N a\rfloor_{s}}{\lfloor C s\rfloor_{s}\lfloor N a\rfloor_{x}}
$$

where $[\mathrm{Cs}]_{\mathrm{x}}$ and $[\mathrm{Na}]_{\mathrm{x}}$ are the cesium and sodium concentrations in the exchanger, respectively, and $[\mathrm{Cs}]_{s}$ and $[\mathrm{Na}]_{s}$ are their respective concentrations in the solution phase. Taking logarithms from both sides yields

$$
\log \mathrm{k}_{\mathrm{Cs} / \mathrm{Na}}=\log \mathrm{K}_{\mathrm{d}}+\log [\mathrm{Na}]_{\mathrm{s}}-\log [\mathrm{Na}]_{\mathrm{x}}
$$

As we are discussing trace exchange in radionuclide removal processes, $[\mathrm{Na}]_{x}$ is constant as is the selectivity coefficient $k_{\mathrm{Cs} / \mathrm{Na}}$ at trace concentration, as will be discussed below (Fig. 17). Taking these into account and rearranging yields 


$$
\log K_{d}=-\log [\mathrm{Na}]_{s}+\mathrm{C}
$$

Presenting this in a figure yields a straight line with a slope of -1 at the higher sodium concentration range Figure 16).

Figure 16. Hypothetical curve for an exchanger $\mathrm{X}$ for the ion exchange reaction $\mathrm{XNa}+\mathrm{Cs}^{+} \leftarrow \rightarrow \mathrm{XCs}$ $+\mathrm{Na}^{+}$, presenting the distribution coefficient as a function of sodium concentration. The presented points are initial set concentrations not equilibrium concentrations.

As can be seen, the $K_{d}$ levels at $\mathrm{Na}$ concentration below $10^{-6} \mathrm{~mol} / \mathrm{L}$. This is because the exchanger hydrolysis brings a constant sodium concentration in the solution (Eq. 6). The concentrations presented in Fig. 16 are initial set concentrations, not actual equilibrium concentrations. If we plotted the curve as a function of equilibrium concentration it would end at concentration of about $10^{-6} \mathrm{~mol} / \mathrm{L}$.

$$
\mathrm{XNa}+\mathrm{H}_{2} \mathrm{O} \leftarrow \mathrm{XH}+\mathrm{Na}^{+}+\mathrm{OH}^{-}
$$

The slope in the $\mathrm{Na}$ for $\mathrm{Cs}$ exchange in Fig. 16 was -1 , which is the ratio of their charges. In case the sorbing ion is divalent (such as $\mathrm{Sr}^{2+}$ ) the slope would be -2 .

Furthermore, the $K_{d}$ is dependent on the concentration of sorbing ion (in this case cesium). But before discussing with that in more detail, we will discuss the selectivity coefficient. It is a more fundamental term than distribution coefficient. At least in principle, it is independent of solution concentrations or activities if we use the corrected selectivity coefficient, in which the solution concentrations are corrected with the corresponding activity coefficients (f).

$$
k_{C s / N a}=\frac{\lfloor C s\rfloor_{x}\lfloor N a\rfloor_{s} f_{N a}}{\lfloor C s\rfloor_{s} f_{C s}\lfloor N a\rfloor_{x}}
$$

If we present hypothetical ion-exchange data as a sorption isotherm where the sorbing ion $\left(\mathrm{Cs}^{+}\right)$ concentration in the solution phase is presented as a function of its concentration in the exchanger phase, we obtain a curve similar to that in Fig. 17 (left panel). Up to a certain solution concentration value, the curve is linear (slope of +1 ), which indicates constant selectivity and a constant $K_{d}$ value. Above that value, the selectivity decreases due saturation of most selective sites or because of interference of filling uniform neighbouring sites or because of the fact discussed later for Eq. 7. If we calculate the selectivity coefficient $k$ and plot it against cesium loading (\%) in the exchanger (Fig. 
17, right panel), we see a clear decrease in selectivity as the cesium loading increases. If we had not plotted the cesium loading on a logarithmic scale, we would not have seen the constancy of the selectivity coefficient at low loading typical for ion exchange of radionuclides, which are almost always present only at trace concentrations.

Figure 17. A hypothetical ion-exchange isotherm for cesium ion exchange in an exchanger $X$ (left) and the corresponding selectivity coefficient as a function of cesium loading (right).

Now we come back to the dependence of $K_{d}$ of the sorbing ion. If we plot the $K_{d}$ versus cesium ion concentration in solution we obtain the curve presented in Fig. 18. The $K_{d}$ remains constant as described in the case of Fig. 14. However, what determines the point where the $K_{d}$ starts to decrease (between $10^{-6} \mathrm{M}$ and $10^{-5} \mathrm{M}$ in the case of Fig. 18) For this Lehto and Harjula (41) derived a formula:

$$
K_{d}=\frac{Q}{\frac{\lceil N a\rceil_{S}}{k_{C S / N a}+\lceil C s\rceil_{s}}}
$$

where $Q$ is ion exchange capacity, $[\mathrm{Na}]_{s}$ and $[\mathrm{Cs}]_{s}$ are sodium and cesium concentrations in solution, respectively, and $\mathrm{k}_{\mathrm{Cs} / \mathrm{Na}}$ is the selectivity coefficient (Eq. 7). Ion-exchange capacity is constant and we assume here that the sodium concentration is constant as well. For trace cesium ion exchange, the selectivity coefficient is also constant as described earlier. Now, when the term $[\mathrm{Na}]_{\mathrm{s}} / \mathrm{k}_{\mathrm{Cs} / \mathrm{Na}}$ is larger than $[\mathrm{Cs}]_{s}, \mathrm{~K}_{d}$ remains constant. However, when $[\mathrm{Cs}]_{s}$ becomes larger than $[\mathrm{Na}]_{s} / \mathrm{K}_{\mathrm{Cs}} / \mathrm{Na}_{\mathrm{a}}, \mathrm{K}_{\mathrm{d}}$ starts to decrease. The point where this occurs depends mainly on the sodium ion concentration in the solution phase.

Figure 18. Distribution coefficient of cesium as a function of equilibrium concentration in solution for a hypothetical ion-exchange case. Same data set as in Fig. 17.

As mentioned at the beginning of this section, $\mathrm{K}_{\mathrm{d}}$ is equal to $50 \%$ column breakthrough. Distribution coefficients are typically determined in batch mode by equilibrating a sample of the exchangers with a known volume of the solutions. To represent $50 \%$ breakthrough, the equilibrium in the batch test should be the same as in the column operation at $50 \%$. This can be achieved by using the same equilibrium solution composition in batch tests as observed at $50 \%$ column breakthrough. This in turn requires that sufficiently high solution to exchanger ratios are used in the batch experiment to prevent essential change in solution composition. If an essential change in solution composition 
occurs, overestimated values that do not represent column performance are observed. Critical analysis of a number of publications show that this has taken place in many studies.

To obtain best possible performance in column-mode operation of ion exchangers the following aspects should be taken into account:

- The processing rate should not be too high to observe a steep breakthrough curve. The ion exchange rate of inorganic ion exchangers is often slow and if too high throughput rates are used, the breakthrough starts too early.

- For the same reason (slow ion exchange rate) the grain size of the exchanger should be as small as possible. There are, however, limits for this due to buildup of pressure across the column. To overcome this problem methods to use of inorganic ion exchangers in powderform or as fibres have been developed $(47,48)$.

- From the process engineering point of view the best way to utilize ion exchange bed is to use them in the "merry-go-round" mode in which the last column is removed when breakthrough is observed and a fresh column is placed in the front-end of the series, as has been done in the SARRY process at the Fukushima Daiichi plant (49).

\section{IN MEMORIAM \\ RISTO HARJULA 1956 - 2017}

Professor Risto Harjula, the world's leading expert in inorganic ion-exchange materials, passed away in September 2017. Risto spent his entire research career at the University of Helsinki, Finland, with the exception of a one-year research visit in 1992-1993 to the University of Salford, UK. From 1983 Risto worked on the development of inorganic ion exchangers for the removal of radionuclides from nuclear waste effluents. Our first challenge was to remove radiocesium from highly alkaline, high-salt content waste effluents at the Loviisa nuclear power plant (NPP) in Finland. For this we developed a transition metal hexacyanoferrate product, later manufactured by the Fortum company under the tradename CsTreat. We tested it in the laboratory and later at the end of the 1980s Risto himself performed pilot-scale experiments with actual waste at the Loviisa NPP. He also participated in the start-up of the full-scale industrial process. He was thus involved with the full development, from initial idea through laboratory and pilot-scale testing to 
full industrial-scale process. Later in the 1990s he visited several nuclear plants in the Europe and the USA and advised on how to use the new advanced ion-exchange media. He had a deep understanding of their ion-exchange properties and how they should be utilized in industrial processes. Risto also developed models to predict the performance of the exchangers in solutions of varying composition. In his later years he was also active in recovering valuable metals from various sources for recycling.

Risto received the most pleasure watching his developments lead to practical industrial applications. He had close contact with the Fortum company throughout his entire research career. Today, Fortum manufactures four of the ion-exchange products we have developed. During the last almost 30 years these exchangers have been utilized in various waste treatment processes in approximately 60 nuclear facilities in 27 countries. We may say that Risto's work developed a new industrial line in Finland.

Risto published 75 articles in refereed journals and numerous conference proceedings. In addition to being a researcher, Risto was a beloved teacher. He lectured in basic radiochemistry and nuclear fuel cycle courses, always with passion. Risto received his MSc in 1983 and his PhD in 1993, both from the University of Helsinki. He became a docent in 1998 and a senior lecturer in 2002. In 2016 he received an honorary professorship from the President of Finland. For further details see: https://tuhat.helsinki.fi/portal/fi/persons/risto-harjula.

TEPCO was given a chance to comment this paper but no response was received.

\section{REFERENCES}

1. Gay, A., Gillet, P., Yournel, B., Varet, T., David, L., Prevost, T., Redonnet, C., Piot, G., Jouaville and S., Pagis, G. (2012) Multi-phased, post-accident support of the Fukushima Dai-ichi Nuclear Power Plant. Proceedings of the 2012 Waste Management Conference, February 26 - March 1, 2012, Phoenix, AZ, USA, paper 12246.

2. Tsukada, T., Uozumi, K., Hijikata, T., Koyama, T., Ishikawa, K., Ono, S., Suzuki, S., Denton, M.S., Keenan, R. and Bonhomme, G. (2014) Early construction and operation of highly contaminated water treatment system in Fukushima Diichi Nuclear Power Station (I) - Ion 
exchange properties of KURION herschelite in simulating contaminated water. Journal of Nuclear Science and Technology, 51:886-893.

3. Braun, J. and Barker, T. (2012) Fukushima Daiichi emergency water treatment. Nuclear Plant Journal, January-February 2012: 36-37.

4. Sylvester, P., Milner, T. and Jensen, J. (2013) Radioactive liquid waste treatment at Fukushima Daiichi. Journal of Chemical Technology and Biotechnology, 88:1592-1596.

5. https://www3.fortum.com/products-and-services/power-plant-services/nuclearservices/nuclear-waste-management/nures.

6. Kani, Y., Asano, T., and Tamata, S. (2014) A new adsorbent for simultaneous removal of cesium and strontium, Proceedings of the 2014 Waste Management Conference, March 26, 2014, Phoenix, AZ, USA, paper 14110.

7. Kani, Y., Asano, T., Kamoshida, M., Nishi, T., Kitamoto, Y., Sumiya, T., Noshita, K., and Takahashi, F. (2016) RO concentrated water treatment equipment for risk reduction of contaminated water stored in tank in Fukushima NPS, Proceedings of the 2016 Waste Management Conference, March 6-10, 2016, Phoenix, AZ, USA, paper 16655.

8. Salter, P.F., Sasamoto, H., Apted, M.J. and Yui, M (1999) Geostatistical analysis of groundwater in Japan: Evaluation of the base case groundwater data set. Japan Nuclear Cycle Development Institute. Report JNC TN-8400 99-023.

9. Möller, T., Harjula, R., and Lehto, J. (2003) Ion exchange of ${ }^{85} \mathrm{Sr}$, ${ }^{134} \mathrm{Cs}$ and ${ }^{57} \mathrm{Co}$ in sodium titanolisicate and the effect of crystallinity on selectivity. Separation and Purification Technology 28:13-23.

10. Baacke, M. and Kiss, A., Zeolites, in lon Exchangers, Ed. K. Dorfner, Walter de Gruyter, 1991, p. $473-491$.

11. Reichenberg, D. (1966) Ion exchange selectivity, Ion exchange, Series of advances, Vol. 1, P. 227, Ed. J.A.Marinsky Marcel Dekker.

12. Harjula, R., Lehto, J., Pothuis, J., Dyer, A. and Townsend, R. (1993) Hydrolysis and trace Cs exchange in K- and Na-mordenites. Journal of the Chemical Society, Faraday Transactions, 89:1877-1882.

13. Howden, M. (1987) Radioactive effluent treatment plant - Sellafield reprocessing factory, Proceedings of the Institution of Mechanical Engineers. Part A. Power and Process Engineering. 201:1-15.

14. http://ukinventory.nda.gov.uk/wp-content/uploads/sites/18/2014/04/2D26.pdf 
15. Sherman, J.D. (1984) Ion exchange separations with molecular sieve zeolites, in Zeolites: science and technology, Ed. Ramoa Ribeiro, F., Nato Science Series E.

16. Loos-Neskovic, C. (1998) The treatment of radioactive liquid wastes and the problems connected with the long-term storage of radioelements, in Mineral processing and the environment, Eds. Gallios, G.P. and Matis, K.A., Nato Science Partnership Series: 2.

17. Harjula, R., Lehto, J., Tusa, E., and Paavola, A. (1994) Industrial scale removal of cesium with hexacyanoferrate exchanger - Process development. Nuclear technology 107:272-278.

18. Tusa, E., Paavola, A., Harjula, R., Lehto, J. (1994) Industrial scale removal of cesium with hexacyanoferrate exchanger - Process realization and test run. Nuclear technology 107:279284.

19. Harjula, R., Lehto, J., Paajanen, A., Brodkin, L., and Tusa, E. (2001) Removal of radioactive cesium from nuclear waste solutions with the transition metal hexacyanoferrate ion exchanger CsTreat. Nuclear Science and Engineering 137:206-214.

20. McLean, N. (2005) Disposal of bulk sodium coolant from the prototype fast reactor at the UKAEA Dounreay site, Scotland. Proceedings of the International Conference on Environmental Remediation and Radioactive Waste Management, September 4-8, 2005, Glasgow, Scotland, p. 1-6.

21. Tusa, E., Harjula, R., and Lehto, J. (2003) Use of novel highly selective ion exchange media for minimizing the waste arising from different NPP and other liquids, Proceedings of the 2003 Waste Management Conference, Tucson, AZ, USA.

22. Ceranic, T. (1978) The structure model of an inorganic ion exchanger cobalt(II)hexacyanoferrate(II). Zeitschrift für Naturforschung 33b:1484-1488.

23. Kuznetsov, V.G., Popova, Z.V., and Seifer, G.B. (1970). Russian Journal of Inorganic Chemistry $15: 1084$.

24. Lehto, J., Haukka, S., Harjula, R. and Blomberg, M. (1990) Mechanism of cesium ion exchange on potassium cobalt hexacyanoferrate(II)s, Journal of the Chemical Society Dalton Transactions 3:1007-1011.

25. Lehto, J., Harjula, R., Haukka, S., and Wallace, J. (1989) Solidification of ${ }^{137}$ Cs into potassium cobalt hexacyanoferrate(II) ion exchanger. Proceedings of the 1989 Joint International Waste Management Conference, Kioto, Japan, October 22-28, 1989, Vol. 1, p. 367-369. 
26. Figueiredo, B.R., Cardoso, S.P., Portugal, I., Rocha, J., and Silva, C.M. (2017) Inorganic ion exchangers for cesium removal from radioactive wastewater. Separation \& Purification Reviews, published online.

27. Popa, K., and Pavel, C.C. (2012) Radioactive wastewaters purification using titanosilicates materials. Desalination 293:78-86.

28. Anthony, R.G., Philip, C.V., and Dosch, R.G. (1993) Selective adsorption and ion exchange of metal cations and anions with silico-titanates and layered titanates. Waste Management 13:503-512.

29. Poojary, D.M., Cahill, R.A., and Clearfield, A. (1994) Synthesis, crystal structures, and ionexchange properties of a novel porous titanosilicate. Chemistry of Materials 6:2364-2368.

30. Clearfield, A., Bortun, L.N, and Bortun, A.I. (2000) Alkali metal ion exchange by the framework titanium silicate $\mathrm{M}_{2} \mathrm{Ti}_{2} \mathrm{O}_{3} \mathrm{SiO}_{4} \times \mathrm{nH}_{2} \mathrm{O}(\mathrm{M}=\mathrm{H}, \mathrm{Na})$. Reactive and Functional Polymers 43:85-95.

31. Clearfield, A. (2001) Structure and ion exchange properties of tunnel type titanium silicates. Solid State Sciences 3:103-112.

32. Nyman, M., Nenof, T.M., and Headley, T.J. (2001) Characterization of UOP IONSIV IE-911. Sandia Report SAND2001-0999, Sandia National Laboratories.

33. DePaoli, S.M., and Bostick, D.T. (1998) Process waste water treatment with hydrogen-form CST and chabazite zeolite, Proceedings of the SPECTRUM'98 Meeting, Denver, CO, USA.

34. Chitra, S., Shanmugamani, A.G., Sudha, R., Kalavathi, S. and Biplob, P. (2017) Selective removal of cesium and strontium by crystalline silicotitanates. Journal of Radioanalytical and Nuclear Chemistry 312:507-515.

35. Bray, L.A., Amonette, J.E., Brown, G.N., Kafka, T.N., Yates, S.F. (1995) Efficient separations and processing crosscutting program: Develop and test sorbents, Report PNL-10750 UC2030.

36. Holmquist, A. (2014) Engineered media for removal of fission products from aqueous streams. Proceedings of the 2014 Waste Management Conference, March 2-6, 2014, Phoenix, AZ, USA, paper 14580.

37. https://www.energy.gov/em/articles/srs-workers-install-technology-speed-tank-wasteremoval.

38. Clearfield, A., and Lehto, J. (1988) Preparation, Structure and Ion Exchange Properties of $\mathrm{Na}_{4} \mathrm{Ti}_{9} \mathrm{O}_{20} \times \mathrm{xH}_{2} \mathrm{O}$. Journal of Solid State Chemistry 73;98-106. 
39. Lehto, J., and Clearfield, A. (1987) The ion exchange of strontium on sodium titanate $\mathrm{Na}_{4} \mathrm{Ti}_{9} \mathrm{O}_{20} \times \mathrm{xH}_{2} \mathrm{O}$. Journal of Nuclear and Radioanalytical Chemistry Letters 118:1-13.

40. Lehto, J., Brodkin L., Harjula, R., and Tusa, E. (1999) Separation of radioactive strontium from alkaline nuclear waste solutions with the highly effective ion exchanger SrTreat. Nuclear Technology, 127:81-87.

41. Lehto, J., and Harjula, R. (1999) Selective separation of radionuclides from nuclear waste solutions with inorganic ion exchangers. Radiochimica Acta 86:65-70.

42. Lynch, R.W., Dosch, R.G., Kenna, B.T., Johnstone, J.K., and Nowak, E.J. (1976) The Sandia solidification process - A braod range aqueous waste solidification method, in: Management of radioactive wastes from nuclear fuel cycle, International Atomic Energy Agency, Vienna, p. 361.

43. Hobbs, D. (2013) Properties and uses of sodium titanates and peroxotitanates. Journal of the South Carolina Academy of Sciences. Vol. 9: Iss. 1, Article 8.

44. Peters, T.B., Barnes, M.J., Hobbs, D.T., Walker, D.D., Fondeur, F.F., Norato, S.D., Fink, S.D., and Pulmano, R.L. (2006) Strontium and actinide separations from high level nuclear waste solutions using monosodium titanate 2. Actual waste testing. Separation Science and Technology 41:2409-2427.

45. Tajiri, H., Mimori, T., Miyajima, K., Uchikosi, T., Mizubayashi, H. and Tusa, E. (2000) Experience of test operation for removal of fission product nuclides in TRU-liquid waste and concentrated nitric acid using inorganic ion-exchangers, Proceedings of the 2000 Waste Management Conference, Tucson, AZ, USA.

46. Mori, K., Iwasaki, M., Mimura, H., and Kanda, H. (2015) Development of a granular Sr sorbent manufactured with titanate. Journal of Ion Exchange 26:43-39 (in Japanese, abstract in English).

47. Harjula, R., Lehto, J., Paajanen, A., Tusa, E. and Yarnell, P. (2004) Use of inorganic ion exchange materials as precoat filters for nuclear waste effluent treatment. Reactive and Functional Polymers 60:85-95.

48. Santala, E., Koivula, R., Harjula, R. and Ritala, M. (2018) Electrospun sodium titanate fibres for fast and selective water purification. Environmental Technology (in press).

49. Brown, J.L. (2015) SARRY implementation at Fukushima-Daiichi nuclear facility, http://www.wmsym.org/archives/2012/panels/013-17.pdf. 
